\title{
Presence of Anisakis nematode larvae in Indian mackerel (Rastrelliger spp.) along the Indian Ocean southern coast of East Java, Indonesia
}

\author{
EKO SETYOBUDI", IZANATUR ROHMAH, RIZKA FAUZIANA SYARIFAH, LISA RAMATIA, \\ MURWANTOKO, DINI WAHYU KARTIKA SARI \\ Department of Fisheries, Faculty of Agriculture, Universitas Gadjah Mada. Jl. Flora Gedung A-4, Bulaksumur, Sleman 55281, Yogyakarta, Indonesia. \\ Tel./fax.: +62-274-563062, `email: setyobudi_dja@ugm.ac.id
}

Manuscript received: 7 November 2018. Revision accepted: 29 December 2018.

\begin{abstract}
Setyobudi E, Rohmah I, Syarifah RF, Ramatia L, Murwantoko, Sari DWK. 2019. Presence of Anisakis nematode larvae in Indian mackerel (Rastrelliger spp.) along the Indian Ocean southern coast of East Java, Indonesia. Biodiversitas 20: 313-319. In this study, we aimed to determine the prevalence (P), mean intensity (MI) and site of infection of anisakid larvae (Nematoda) in Indian mackerel (Rastrelliger spp.) at the Indian Ocean Southern Coast of East Java. A total of 341 fish were collected from Prigi and Muncar Fish Harbor, East Java during March-April 2018. Each fish specimen was measured in body length and weight, and then dissected for examination of Anisakis larvae in the body cavity, digestive tract, liver, gonad and muscle. The collected larvae were preserved in absolute ethanol for both morphological and molecular identification. The results of this research showed Indian mackerel was susceptible to Anisakis infection ( $\mathrm{P}=17 \%, \mathrm{MI}=6.8$ larva/individual fish). Most of the larvae were found in the digestive tract and body cavity, $47.2 \%$ and $46.0 \%$ respectively. Only a few larvae were found in other internal organs and muscle. Based on morphological identification, these larvae corresponded to Anisakis Type I. Furthermore, in molecular identification using PCR-RFLP, the banding pattern clearly matched with Anisakis typica. The prevalence and mean intensity of Anisakis nematodes on Indian mackerel along the southern coast of East Java seem to be different in each locality and from other adjacent waters as has previously been reported, which may be due to differences in feeding habits and in the distribution of marine mammals as the final host. The results suggest that differences in prevalence and mean intensity of anisakis larvae infection could be developed as a biological indicator of fish stock discrimination. However, clear information regarding food habits of Indian mackerel and migration patterns of the paratenic hosts as well as of marine mammals as final host is needed.
\end{abstract}

Keywords: Anisakis prevalence, East Java, Indian Ocean, Rastrelliger

\section{INTRODUCTION}

Anisakis nematodes belonging to the Anisakidae family are frequently found in marine fish, and live in hosts at various trophic levels of the food chain (Lymbery and Cheah 2007). Their life cycle involving small crustaceans as an intermediate host, fish and cephalopods as paratenic hosts, and marine mammals as final hosts. Humans become an accidental host of Anisakis larvae usually as a result of consuming infected raw fish or imperfectly cooked fish (Audicana et al. 2003; Ivanovic et al. 2017). Anisakis infection in human causes an acute gastrointestinal infection with several symptoms such as abdominal pain, diarrhea, nausea and vomiting, a condition known as anisakiasis (Ivanovic et al. 2017; Bao et al. 2018).

The presence of Anisakis larvae in fishery products has an impact on the commercial fishing industry due to reduction in product quality, aesthetic appearance and economic value (Aspholm 1995; Molnar et al. 2006). In addition to the negative impacts on health and the economy, the occurrence of anisakis can be used as a biological tag in various ecological studies. The use of parasites as biological indicators of various fish species and cephalopods increased rapidly after appropriate guidelines and methodologies were developed (MacKenzie 1987; Williams et al. 1992; MacKenzie and Abaunza 1998).
Anisakis species have been used to identify aspects of the ecology and natural history of various host species. Variations in prevalence and infection levels of Anisakis larvae have been used as biological tags for stock or population studies such as for estimating growth rates, migration patterns and food habits of host species (Williams et al. 1992; Konishi and Sakurai 2002). Of the various types of parasites that have been used for stock studies, the genus Anisakis, which has been genetically identified to species level using allozyme markers, has provided useful information for stock studies in a multidisciplinary approach (Mattiucci et al. 2007). For example, the occurrence of Anisakis spp. and others macroparasites seems to be a crucial biological tag for stock identification of bluemouth rockfish, Helicolenus dactylopterus (Sequeira et al. 2010).

Indonesia is an archipelago rich in marine biodiversity and with a very extensive area of ocean. However, there is a lack of information regarding fish parasites in Indonesian waters (Palm et al. 2017). Anisakis larvae have been reported infecting various marine fish species in Indonesia (Hutomo et al. 1978; Palm et al. 2008; Setyobudi et al. 2011a; Anshary et al. 2014; Palm et al. 2017). Indian mackerel (Rastrelliger spp.) is listed as one fish species known to be susceptible to infection by Anisakis larvae. Indian mackerel is a pelagic fish widely distributed in the 
Indo-Pacific region and abundant in Indonesia (Collete and Nauen 1983). Information related to Anisakis infection is very important for efforts to prevent cases of human anisakiasis, as well as in the development of biological tags marine ecological studies. Up to now, there has been no specific investigation related to Anisakis larvae infection of Indian mackerel in the Indian Ocean along the southern coast of East Java. This study aimed to determine the prevalence, mean intensity of infection and target organs of Anisakis larvae infecting Indian mackerel, and to identify the nematode definitively using both morphological and molecular approaches.

\section{MATERIALS AND METHODS}

\section{Nematode collection}

Anisakis worms were collected from 341 Indian mackerel caught from the Indian Ocean southern coast of East Java (Figure 1), during March-April 2018 (Table 1). Each fish sampled was measured for total length and body weight. Anisakis larvae collection was conducted by dissecting and examining the body cavity, internal organ (liver, digestive tract, gonads) and muscle. Larvae were collected, then washed with $0.9 \% \mathrm{NaCl}$ solution, then preserved using absolute ethanol in preparation for morphological and molecular identification. Population descriptors used are prevalence (a number of hosts infected with parasites divided by the number of hosts examined) and mean intensity (average of infection of parasite among the infected fish) (Bush et al. 1997).

\section{Morphological identification}

Morphological identification of Anisakis was conducted on 30 selected samples. Larvae were cleared by immersing them in glycerin: lactic acid: phenol: DW solution (2: 1: 1: 1) for approximately 24 hours. They were then placed on an object glass using Canada balsam. Morphological identification was conducted based on the shape of the ventriculus, the anterior and posterior ends, following the keys previously reported (Murata et al. 2011).

\section{Molecular identification}

DNA was extracted from larvae following the extraction guide in the Geneaid DNA Mini Kit. Molecular identification was carried out by PCR-RFLP analysis and sequencing. PCR-RFLP is performed on ribosomal DNA (rDNA). The ITS region (ITS1-5.8S-ITS2) of rDNA was amplified using primer A (5'-GTC GAA TTC GTA GGT GAA CCT GCG GAA GGA TCA-3 ') and primer B (5'GCC GGA TCC GAA TCC TGG TTA GTT TCT TTT CCT-3') (D 'Amelio et al. 2000). The amplification product was analyzed by the RFLP technique using the TaqI, HinfI, and HhaI restriction enzymes (D'Amelio et al. 2000; Umehara et al. 2006).

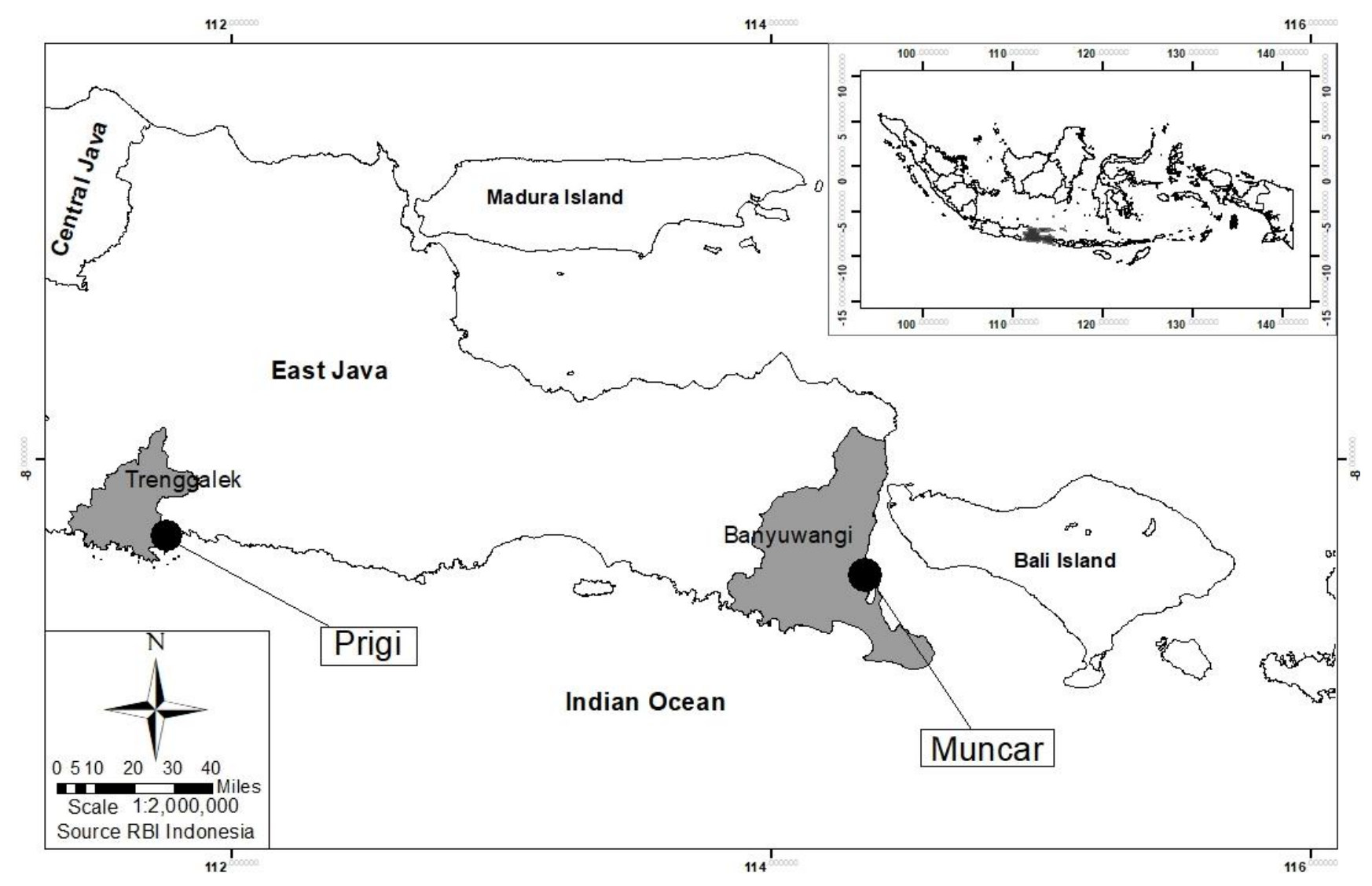

Figure 1. Fish sampling sites on the Southern Coast of East Java, Indonesia 
The genetic relationship of sampled Anisakis among other related species that have been published was conducted based on mtDNA (mitochondrial DNA) cox2 genes. The mtDNA (mitochondrial DNA) cox2 region were amplified using primers 210 (5'-CAC CAA CTC TTA AAA TTA TC-3 ') and 211 (5'-TTT CTA GTT ATA TAG ATT GRT TYA T-3') (Nadler and Hudspeth 2000). DNA sequencing was carried out at the 1st Base Laboratory in Singapore through PT Genetika Science Indonesia. The sequence of mtDNA cox 2 region was processed using Bioedit software and BLAST analysis was carried out to characterize the sampled species and determine its similarity to other species previously reported in GenBank. A phylogenetic tree was constructed using Mega 7.0.26 software (Kumar et al. 2016), then used for comparing the genetic relationship to other published sequences.

\section{RESULTS AND DISCUSSION}

\section{Results}

The results showed that Indian mackerel from the Indian Ocean southern coast of East Java was susceptible to infection by Anisakis larvae. The prevalence and mean intensity of Anisakis larvae infection were different between waters in the Prigi and Muncar locations (Figure 1). Although the prevalence was only a little bit different, the mean intensity of Anisakis larvae on Indian mackerel from Prigi was higher (2-3 times) compared to Indian mackerel from Muncar (Table 1).

The prevalence and mean intensity of Anisakis larvae infecting mackerel (Rastrelliger spp.) increased in relation to increase in fish body length (Figure 2). The lowest prevalence and mean intensity were found in fish size 17.0$22.9 \mathrm{~cm}$, while the highest were found in fish measuring $\geq 29 \mathrm{~cm}$. Anisakis larvae infection was not found in fish with body length less than $16.9 \mathrm{~cm}$. The mean intensity of Anisakis larvae was relatively low (6.8 larvae/individual).

Most of the Indian mackerel infected by Anisakis larvae had only a low intensity of infection, i.e., 1-5 larvae/individual (Figure 3). There were the different distribution of hosts which infected in low intensity (less than 5 larvae/individuals) from each locality that is $69.2 \%$ in mackerel originating from Prigi and $84.4 \%$ in mackerel originating from Muncar. Very few infected Indian mackerel had more than 20 larvae/individuals. The fish hosts with high intensity (more than 25 larvae/individual) were only found in mackerel originating from Prigi (less than $11.4 \%$ from total infected hosts).

Anisakis larvae were mostly found in the digestive tract (47.2\%) and body cavities $(46.0 \%)$ and only very few of Anisakis larvae were found in the liver (3.5\%), gonads $(1.5 \%)$ and muscle (1.8\%) (\% from total larvae found).

Morphological identification indicated that Anisakis larvae infecting mackerel along the Indian Ocean southern coast of East Java were of Type I Anisakis, characterized by long ventricles and the presence of mucron on the posterior end (Figure 4). Ten selected samples were used for PRC-RFLP analyses, while the nucleotide sequencing of mt-cox 2 genes was carried out on four samples.. Amplification of the rDNA region resulted in approximately $1 \mathrm{kbp}$ product. Digestion of PCR product using HhaI, HinfI and TaqI restriction enzymes resulted in different banding patterns that were used for Anisakis identification (Figure 5).

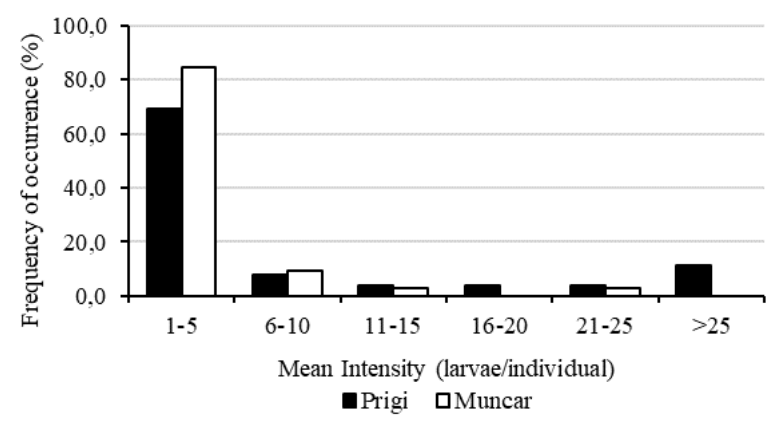

Figure 3. Distribution of parasitic intensity
Figure 2. Correlation between body length and the occurrence of

Anisakis larvae in Indian mackerel

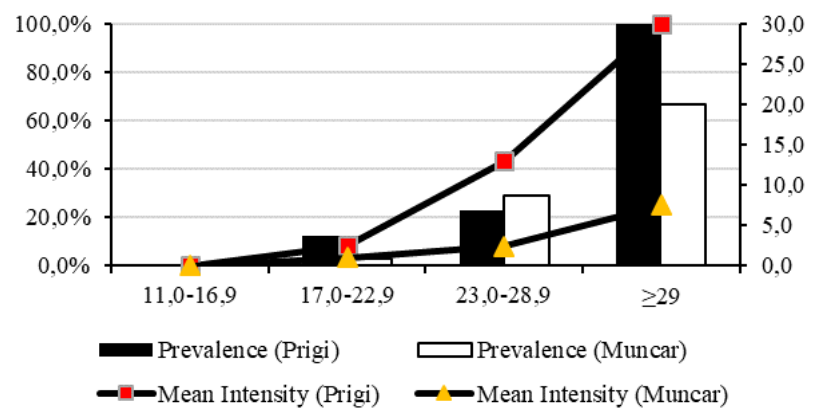

Table 1. Number of samples, prevalence, and intensity of Anisakis larvae

\begin{tabular}{lccccc}
\hline \multicolumn{1}{c}{ Location } & $\begin{array}{c}\text { Number of samples } \\
(\mathbf{n})\end{array}$ & $\begin{array}{c}\text { Length } \\
(\mathbf{c m})\end{array}$ & $\begin{array}{c}\text { Weight } \\
(\mathbf{g})\end{array}$ & $\begin{array}{c}\text { Prevalence } \\
(\boldsymbol{\%})\end{array}$ & $\begin{array}{c}\text { Mean intensity } \\
(\text { larvae/individual) }\end{array}$ \\
\hline Prigi Fishing Port & 139 & $15.4-29.5$ & $39.5-320.5$ & 18.7 & 11.2 \\
Muncar Fishing Port & 202 & $12.7-31.9$ & $18.5-421.5$ & 15.8 & 3.3 \\
Total & 341 & $12.7-31.9$ & $39.5-320.5$ & 17.0 & 6.8 \\
\hline
\end{tabular}



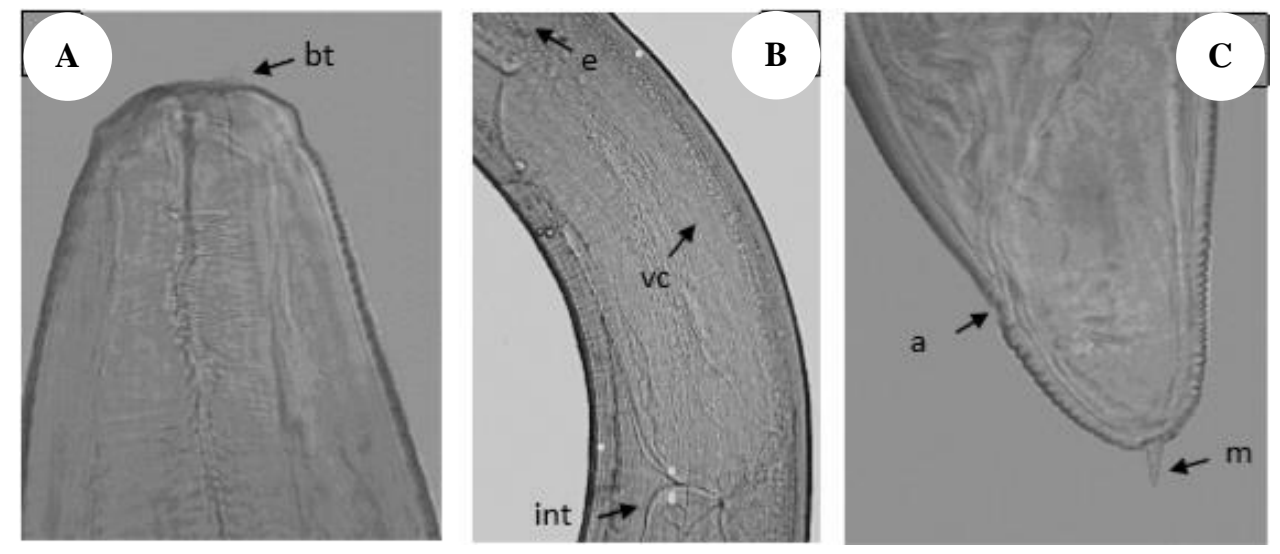

Figure 4. Morphology of Anisakis Type I from Indian mackerel. A. Chepalic region; B. Ventrivular part; C. Caudal end. $b t$ boring tooth, $e$ esophagus, $v c$ ventriculus, int intestinum, $a$ anus, $m$ mucron

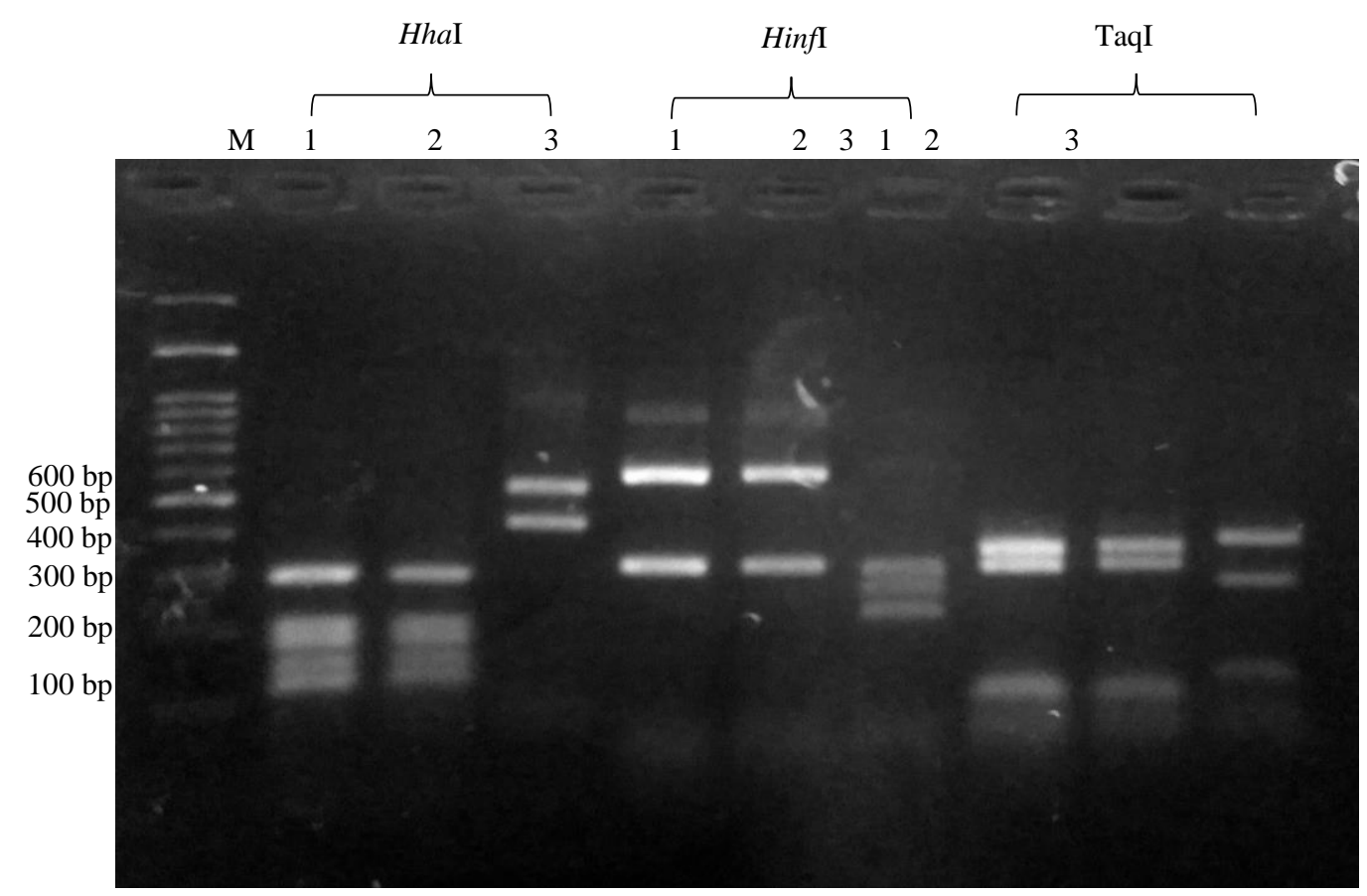

Figure 5. Restriction fragment length polymorphism pattern obtained by digestion of the internal transcribed spacer (ITS) region of rDNA with the restriction enzymes HhaI, HinfI and TaqI. (M) 100 bp marker; (1) Anisakis larvae isolated from Rastrelliger spp. (originated from Muncar waters); (2) Anisakis larvae isolated from Rastrelliger spp. (originated from Prigi waters) (3) Anisakis larvae isolated from Scomber sp. Pattern 1 and 2 A. typica; Pattern 3 A. pegreffii

Table 2. Identification of Anisakis larvae using PCR-RFLP method with reference to D'Amelio et al. (2000)

\begin{tabular}{lllll}
\hline Samples & HhaI & HinfI & TaqI & Species \\
\hline 1 & $320-240-180-160$ & $620-350$ & $400-350$ & typica \\
2 & $320-240-180-160$ & $620-350$ & $400-350$ & typica \\
3 & $550-430$ & $370-300-250$ & $400-320-150$ & pegreffii \\
\hline
\end{tabular}

Note: (1) Anisakis larvae isolated from Rastrelliger spp. (Muncar waters); (2) Anisakis larvae isolated from Rastrelliger spp. (Prigi waters); (3) Anisakis larvae isolated from Scomber sp.
Digestion of PCR product using HhaI restriction enzyme produced bands at $320 \mathrm{bp}, 240 \mathrm{bp}, 180 \mathrm{bp}$, and 160 bp, Hinfl produced 620 bp and 350 bp bands, while using TaqI produced $400 \mathrm{bp}$ and $350 \mathrm{bp}$. Molecular identification carried out by the PCR-RFLP method, resulted in banding patterns which corresponded to Anisakis typica, according to D'Amelio et al. (2000).

Phylogenetic trees derived from the nucleotide sequence of the mtDNA cox 2 gene and comparison with nucleotide sequences that were previously reported at NCBI, confirm that all samples examined in this study were A. typica (Figure 6). 


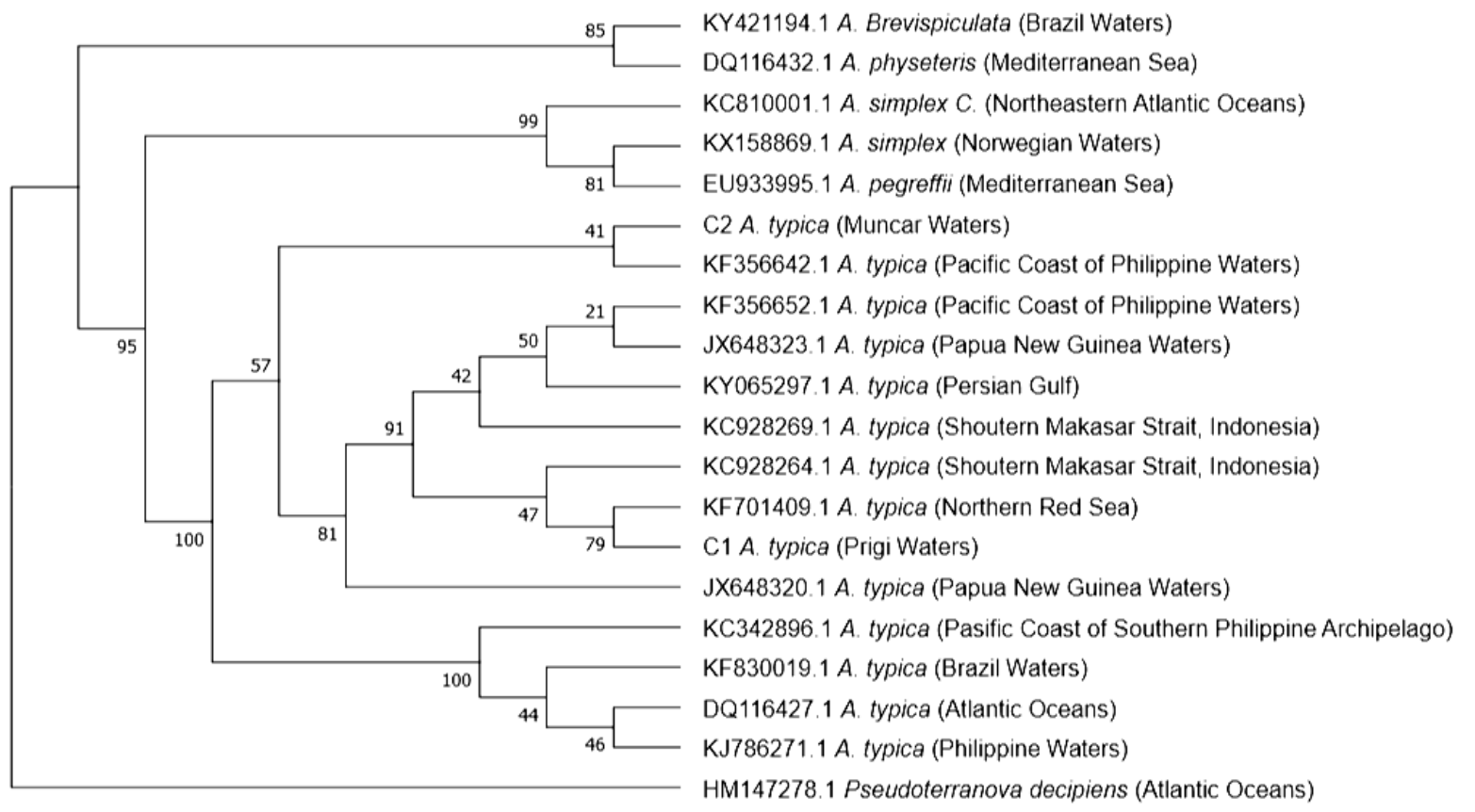

Figure 6. Phylogenetic tree based on mtDNA cox2 gene sequences exploring the relationships among Anisakis species

\section{Discussion}

Indian mackerel caught from Indian Ocean southern coast of East Java were susceptible to Anisakis larvae infection, with a relatively low prevalence and mean intensity $(\mathrm{P}=17.0 \% ; \mathrm{MI}=3.3$ larvae/individual $)$. However, this infection was higher than infection levels of Anisakis larvae in Indian mackerel caught in Makassar waters ( $\mathrm{P}=3.3 \%$; $\mathrm{MI}=1$ larva/individual) (Anshary 2011). The prevalence and mean intensity of Anisakis nematodes in Indian mackerel at the southern coast of East Java seem to be different in each locality, which might make it possible to for Anisakis larvae data to be used as a biological indicator for fish stock discrimination. Konisi and Sakurai (2002) reported variations of anisakid nematode infection in walleye pollock (Theragra chalcogramma) of Japanese waters, which was related to differences in growth and host feeding habits. The differences in the distribution of Anisakis species larvae have been used to characterize demersal fish stocks of small and large pelagic fish in European waters (Mattiuci et al. 2007). The level of infection seems to differ depending on fish host capture location. According to Aspholm (1995), the infection level of Anisakis larvae is influenced by food composition of fish host and the distribution of cetaceans as the final hosts of Anisakis. Fish and shrimp are the main food components of Indian mackerel in Prigi waters compared with fish caught in Muncar waters. This condition caused higher risk of infection by Anisakis larvae. The higher infection level of mackerel caught in Prigi waters could also be due to other ecological factors such as the distribution of marine mammals as a final host, which are abundant in these waters.

Anisakis infection in mackerel caught at the southern coast of East Java tends to increase in line with the increasing fish body size (Figure 2). The positive relationship between host length and the infection level of Anisakis larvae infection has been shown in several previous studies (Konishi and Sakurai 2002; Cruz et al. 2009; Setyobudi et al. 2011b; Abou-Rahma et al. 2016; Casti et al. 2017). Increased levels of Anisakis larvae infection caused by the accumulation of larvae during the lifespan of the fish, is a likely reason for adult fish (largesized) having a higher infection level. In addition, the total amount of food consumed by fish will increase with increasing fish age and size; since Anisakis infection occurs through the predatory process, then the infection level would be predicted to be higher in adult fishes. Indian mackerel with 11.0-16.9 $\mathrm{cm}$ body length were shown not to be infected with Anisakis larvae in this study (Figure 2).

The absence of Anisakis infection in small mackerel was possibly due to differences in food habits between young and adult mackerel. The food habit of mackerel seems to change during their life. The main food of young mackerel is small phytoplankton and zooplankton. However, adult mackerel, with their sharp teeth, prey on macroplankton in the form of shrimp, fish, and squid larvae (Collete and Nauen 1983; Nath et al. 2015). Research on food and feeding habits of mackerel in the Mangalore India showed that zooplankton $(41.56 \%)$ and phytoplankton $(37.64 \%)$ were the main food of young mackerel (Hulkoti et al. 2013). Another study by Nath et al. (2015) showed that the composition of food in the digestive tract of mackerel originating from the Red Sea is mainly crustaceans $(60.48 \%)$ and fish $(22.42 \%)$. The absence of Anisakis larvae in small mackerel $(11.0-16.9 \mathrm{~cm})$ in this study is thought to be due to a planktivorous feeding habit of small mackerel which tend to be herbivores. 
Anisakis larvae were mostly found in the digestive tract $(47.2 \%)$ and body cavities $(46.0 \%)$, and only a few were found in other organs and muscle. Initially, Anisakis larvae enter the body of fish through eating infected crustacean/fish, then the larvae move to the digestive tract. The digestive tract is the first location during the early period of infection. The digestive tract is a suitable microhabitat for parasitic worms including Anisakis larvae due to it containing organic material that is readily absorbed as food by the parasitic worms. Mattiucci et al. (2018) mention that Anisakis species seem to have preferential infection sites in their fish hosts, which appears to be dependent not only on the Anisakis species but also on the fish host species.

Morphological identification in our study indicated that Anisakis larvae infecting mackerel along the Indian Ocean southern coast of East Java were of Type I Anisakis, characterized by long ventricles and the presence of mucron on the posterior end (Berland 1961). Molecular identification by the methods of PCR-RFLP and nucleotide sequencing confirmed that the nematodes belong to the species A. typica. Previous studies have also reported that most of the Anisakis larvae infecting various fishes in Indonesian waters are identified as A. typica (Anshary et al. 2014; Palm et al. 2017). A. typica populations have been detected genetically in a wide geographic range, extending from $30 \mathrm{~S}$ to $35 \mathrm{~N}$ in warmer temperate and tropical waters. A. typica has been reported from marine fishes around the world such as in Korea, Japan, China, Portugal, Taiwan, Brazil, Maroco, Papua New Guinea and the Mediterranean Sea (Zhu et al. 2007; Farjallah et al. 2008; Umehara et al. 2010; Koinari et al. 2013). So far, the known final hosts of A. typica are dolphins from the family Delphinidae, Phocoenidae, and Pontoporidae (Mattiucci et al. 2002).

The nucleotide sequence of mtDNA cox 2 gene shows that A. typica which infects mackerel in Prigi and Muncar waters have a similarity of $96 \%$ between the two locations, with 22 nucleotide composition differences (569/591 bp). The differences in nucleotide composition indicate variation or genetic diversity between A. typica in the two sites. This study suggests quite a high level of genotypic variability in A. typica isolated from Indian mackerel on the southern coast of East Java. The similar variability of $A$. typica genotypes was reported in Balinese waters (Palm et al. 2017). Based on the phylogenetic tree that was constructed in this study, A. typica isolated from mackerel in the south coast of East Java has a close relationship with A. typica from other places. There are two groups of $A$. typica, the first is A. typica from the Philippines, the Atlantic Ocean, Brazil and the South Pacific Coast of the Philippines, while the second group is A. typica from Indonesia, Philippines, Papua New Guinea, Persia and the North Red Sea (Figure 7). The close relationship between each group is suspected to be due to the proximity of geographical area which allows genetic flow between the regions.

Anisakis is known to cause zoonotic parasitic disease that has become an emerging issue in developed countries. Although, to date, there have been no reports of cases of Indonesian anisakiasis, changes in lifestyle with the consumption of raw or uncooked fish in dishes like sashimi and sushi may increase the risk of human anisakiasis. In addition to the negative effects, the presence of anisakis has been developed and used as a biological indicator in many ecological studies. Anisakis parasites can be used as indicators for fish growth studies, recruitment, death, migration behavior and host eating habits (Williams et al. 1992; MacKenzie 2002).

\section{ACKNOWLEDGEMENTS}

This research was funded by a Universitas Gadjah Mada grant, Number: 91/UN1/DITLIT/DIT-LIT/LT/2018.

\section{REFERENCES}

Abou-Rahma Y, Abdel-Gaber R, Ahmed AK. 2016. First record of Anisakis simplex third-stage larvae (Nematoda, Anisakidae) in European Hake Merluccius merluccius lessepsianus in Egyptian Water. J Parasitol Res. ID 9609752, DOI: 10.1155/2016/9609752

Anshary, H. 2011. Molecular identification of Anisakis spp. (Nematode: Anisakidae) from frigate tuna (Auxis thazard) and Indian mackerel (Rastrelliger kanagurta) of Makasar Waters. J Fisher Sci 13 (2): 7077. [Indonesian]

Anshary H, Sriwulan, Freeman MA, Ogawa K. 2014. Occurrence and molecular identification of Anisakis Dujardin, 1845 from marine fish in Southern Makasar Strait, Indonesia. Korean J Parasitol 52 (1): 919.

Aspholm PE. 1995. Anisakis simplex Rudolphi, 1809, infection in fillets of Barents Sea cod Gadus morhua L. Fisher Res 23: 375-379.

Audicana MT, del Pozo MD, Iglesias R, Ubeira FM. 2003. Anisakis simplex and Pseudoterranova decipiens. In: Miliotis MD, Bier JW (eds) International Handbook of Foodborne Pathogens. Marcel Dekker, Inc. New York.

Bao M, Pierce GJ, Srachan NJC, Martinez C, Fernandez R, Theodossiou I. 2018. Consumers attitude and willingness to pay for anisakis-free fish in Spain. Fisher Res 202: 149-160.

Berland B. 1961. Nematode from some Norwegian marine fishes. Sarsia 2: $1-50$.

Bush AO, Lafferty KD, Lotz JM, Shostak AW. 1997. Parasitology meets ecology on its own terms: Margolis et al. revisited. J Parasitol 83: 575-583.

Casti D, Scarano C, Piras MC, Merella P, Muglia S, Piras F, Garipta G, Spanu C, de Santis EPL. 2017. Occurrence of nematodes of genus anisakis in Mediterranean and Atlantic fish marketed in Sardina. Italian J Food Saf 618 (6): 5-8.

Collete BB, Nauen CE. 1983. FAO Species Catalogue. Vol 2. Scombrids of The World. An Annotated and Illustrated Catalogue of Tunas, Mackerels, Bonitos, and Related Species Known to Date. FAO Fish Synop 2 (125): 137 p.

Cruz C, Saraiva A, Santos MJ, Eiras JC, Ventura C, Soares JP, Hermida M. 2009. Parasite infection levels by Anisakis spp. larvae (Nematoda: Anisakidae) in the black scabbarfish Aphanopus carbo (Osteichthyes: Trichiuridae) from Portuguese Water. Scientia Marina 73: 115-120.

D'Amelio S, Mathiopoulos KD, Santos CP, Pugachev ON, Webb SC, Picanco M, Paggi L. 2000. Genetic markers in ribosomal DNA for the identification of members of the genus (Nematoda: Ascaridoidea) defined by polymerase chain reaction-based restriction fragment length polymorphism. Intl J Parasitol 30: 223-226.

Farjallah S, Slimane BB, Busi M, Paggi L, Amor N, Blel H, Said K, D'Amelio S. 2008. Occurrence and molecular identification of Anisakis spp. from the North African coasts of Mediterranean Sea. Parasitol Res 102: 371-379.

Hulkoti SH, Shivaprakash SM, Anjanayappa HN, Somashekara SR, Benakappa S, Naik ASK, Prasad LG, Kumar J. 2013. Food and feeding habits of mackerel Rastrelliger kanagurta (Cuvier) from Mangalore Region. Environ Ecol 31 (2A): 672-675. 
Hutomo M, Burhanuddin, Hadidjaja P.1978. Observations on the incidence and intensity of infection of nematode larvae (Fam. Anisakidae) in certain marine fishes of waters around Panggang Island, Seribu Islands. Mar Res Indon 21: 49-60.

Ivanovic J, Baltic MZ, Boskovic M, Kilibarda N, Dokmanovic M, Markovic R, Janjic J, Baltic B. 2017. Anisakis allergy in human Trends Food Sci Technol 59: 25-29.

Koinari M, Karl S, Elliot A, Ryan U, Lymbery AJ. 2013. Identification of Anisakis species (Nematoda: Anisakidae) in marine fish hosts from Papua New Guinea. Vet Parasitol 193 (1-3): 126-133.

Konishi K, Sakurai Y. 2002. Geographical in variation in infection by larval Anisakis simlex and Contracaecum asculatum (Nematoda, Anisakidae) in Walleye Pollock Theragra chalogramma stock off Hokkaido, Japan. Fisher Sci 68: 534-542.

Kumar S, Stecher G, Tamura K.2016. MEGA7: Molecular Evolutionary Genetics Analysis Version 7.0 for Bigger Datasets. Mol Biol Evol 33 (7): 1870-1874

Lymbery AJ, Cheah FY. 2007. Anisakid nematodes and anisakiasis. In: Murrell KD, Fried B. Food-Borne Parasitic Zoonoses: Fish and PlantBorne Parasites (World Class Parasites). Springer Science, p: 185207.

MacKenzie K. 1987. Parasites as indicator of host population. Int J Parasitol 17: 345-342.

MacKenzie K, Abaunza P. 1998. Parasites as biological tags for stock discrimination of marine fish: a guide to procedures and methods. Fish Res 38: 45-56.

MacKenzie, K. 2002. Parasites as biological tags in population stuidies of marine organisms: an update. Parasitology 124: 153-163.

Mattiucci S, Paggi L, Nascetti G. Santos CP, Costa G, Di Beneditto AP, Ramos R, Argyrou M, Cianchi R, Bullini L. 2002. Genetic markers in the study of Anisakis typica (Diesing, 1860): larval identification and genetic relationships with other species of Anisakis Dujardin, 1845 (Nematoda: Anisakidae). Syst Parasitol 51 (3): 159-170.

Mattiucci S, Abaunza P, Damiano S, Garcia A, Santos MN, Nascetti G. 2007. Distribution of anisakis larvae, identified by genetic markers, and their use for stock characterization of demersal and pelagic fish from European Waters: an update. J Helminthol 81: 117-127.

Mattiucci S, Capriani P, Levsen A, Paoletti M, Nascetti G. 2018 Molecular epidemiology of Anisakis and Anisakiasis: An ecological and evolutionary road map. Adv Parasitol 99: 93-263.

Molnar K, Buchmann K, Szekely C. 2006. Phylum Nematoda. In: Woo PTK (ed) Fish Disease and Disorders Vol 1: Protozoan and Metazoan Infections, 2nd ed. CAB International, UK.
Murata R, Suzuki J, Sadamasu K, Kai A. 2011. Morphological and molecular characterization of anisakis larvae (Nematoda: Anisakidae) in Beryx splendens from Japanese Waters. Parasitol Intl 60: 193-198.

Nadler SA, Hudspeth DSS. 2000. Phylogeny of the Ascaridoidea (Nematoda: Ascaridida) based on three genes and morphology: hypotheses of structural and sequence evolution. J Parasitol 86: 380393

Nath SR, Beraki T, Abraha A, Abraham K, Berhane Y. 2015. Gut content analysis of Indian mackerel (Rastrelliger kanagurta). J Aquacult Mar Biol 3 (10): 1-5.

Palm HW, Damriyasa IM, Linda, Oka IBM. 2008. Molecular genotyping of Anisakis Dujardin, 1845 (Nematoda: Ascaridoidea: Anisakidae) larvae from marine fish of Balinese and Javanese Water, Indonesia. Helminthologia 45: 3-12.

Palm HW, Theisen S, Damriyasa IM, Kusmintarsih ES, Oka IBM, Setyowati EA, Suratma NA, Wibowo S, Kleinertz S. 2017. Anisakis (Nematoda: Ascaridoidea) from Indonesia. Dis Aquat Org 123: 141157.

Setyobudi E, Senny H, Soeparno. 2011a. Infection of Anisakis sp. larvae in some marine fishes from the southern coast of Kulon Progo, Yogyakarta. Biodiversitas (1) 1: 34-37.

Setyobudi E, Jeon CH, Lee CH, Seong KB dan Kim JH. 2011 b. Occurrence and identification of Anisakis spp. (Nematoda: Anisakidae) isolated from chum salmon (Oncorhynchus keta) in Korea. Parasitol Res 108: 585-592.

Sequeira V, Gordo LS, Neves A, Paiva RB, Cabral HN, Marques JF. 2010. Macroparasites as biological tags for stock identification of the bluemouth, Helicolenus dactylopterus (Delaroche, 1809) in Portuguese waters. Fish Res 106: 321-328

Umehara A, Kawakami Y, Matsui T, Araki J, Uchida A. 2006. Molecular identification of Anisakis simplex sensu stricto and Anisakis pegreffii (Nematoda: Anisakidae) from fish and cetacean in Japanese waters. Parasitol Intl 55: 267-271

Umehara A, Kawakami Y, Ooi HK, Uchida A, Ohmae H, Sugiyama H. 2010. Molecular identification of Anisakis Type I larvae isolated from hairtail fish off the Coast of Taiwan and Japan. Intl J Food Microbiol 143: 161-165.

Williams HH, MacKenzie K, McCarthy AM. 1992. Parasites as biological indicators of the population biology, migration, diet, and phylogenetics of fish. Rev Fish Biol Fisher 2: 144-176.

Zhu XQ, Podolska M, Liu JS, Yu HQ, Chen HH, Lin ZX, Luo CB, Song HQ, Lin RQ. 2007. Identification of anisakid nematodes with zoonotic potential from Europe and China by single-strand conformation polymorphism analysis of nuclear ribosomal DNA. Parasitol Res 101: 1703-1707. 